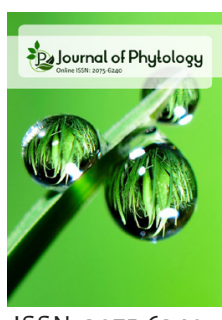

ISSN: $2075-6240$

\title{
Seaweed effects on plant growth and environmental remediation: A review
}

\author{
Umar Aliyu Abdullahi, ${ }^{1,2}$, Mohammad Moneruzzaman Khandaker"*, \\ Nadiawati Alias', Elyni Mat Shaari', Md. Amirul Alam³, \\ Noor Afiza Badaluddin', Khamsah Suryati Mohd'
}

'School of Agriculture Science and Biotechnology, Faculty of Bioresources and Food Industry, Universiti Sultan Zainal Abidin, Besut Campus, 22200 Besut, Terengganu, Malaysia, ${ }^{2}$ Department of Microbiology and Biotechnology, Federal University Dutse, Jigawa, Nigeria, ${ }^{3}$ Faculty of Sustainable Agriculture, Horticulture and Landscaping Program, Universiti Malaysia Sabah, Sandakan, Sabah, Malaysia

Received: February 13, 2021 Revised: August 25, 2021 Accepted: August 27, 2021 Published: September 17, 2021

\section{*Corresponding Author:} Mohammad Moneruzzaman Khandaker

E-mail: moneruzzaman@unisza. edu.my

\section{ABSTRACT}

Seaweeds are plants found in the sea that have tremendous applications in the fields of agriculture and environment. It comprises three giant classes with a large number of different species and their ability to adapt to the various conditions qualifies them more applicable to various environmental and agricultural arena. Agriculturally, both three classes Phaeophyta, Rhodophyta and Chlorophyta, have significant roles in promoting plant growth and productivity and soil protection as well as its reclamation with class Phaeophyta have the highest contribution due to its alginic acid content and other multifaceted components that are higher followed by Rhodophyta and Chlorophyta. Seaweed (living or dead biomass) has the ability to phycoremediate environment against heavy toxic metals and lessen the excessiveness of non-metal inorganic elements via physisorption, chemisorption with the aid of binding sites provided by proteins and carbohydrates functional groups existing in their cell walls and secretion of organic acids and intracellular transformation and accumulation. Seaweed is an important factor in environmental remediation and soil restoration processes

KEYWORDS: Seaweeds, plant growth, soil revival, drought, phycoremediation
The universal anthropogenic activities and negative climatic vagaries have established a rise in atmospheric pollution and temperature, salinization of soil, and metal toxicity and these evoke diminished agricultural production effects and the grade of the crop (Dos Reis et al., 2012) and animals and humans wellbeing. Any environmental contaminations are available to detriment of the lives of a surrounding organism. Seaweed also called marine/macroalgae are non-flowering primitive, photosynthetic macrophytes and naturally renewable found in oceans around the tidal regions that occupies up to $71 \%$ of the world. Green, brown and red seaweeds are widely spread in the tidal, intertidal and subtidal areas respectively (Rao et al., 2018). Macroalgae are bigger, having a simple thallus structure without true leaf and roots, they have pseudo roots known as hold fasts/rhizoids. Algae possess chlorophyll-a, b, c and contain protein, carbohydrate and other plant products akin to those of higher plants. They do photosynthesis through their thallus (Dawson et al., 1966; Goecke et al., 2010). Algae are considered as a primary source of organic compound in an aquatic environment and hence it plays a crucial role in the food chain (Shalaby, 2011). According to Okolie et al. (2018) seaweeds are macroscopically multi-cellular organisms that dwell in coastal, marine ecosystems and are the wellspring of enzymes, polyunsaturated fatty acids, polysaccharides, bioactive peptides, among others. They supply the oxygen required for the metabolism among the consuming organisms. Additionally, macroalgae have been evidenced to procure a rich source of natural bioactive compounds with hypolipidemic, anti-inflammatory, antioxidant, hypercholesterolemia, antineoplastic, antifungal, antiviral and antibacterial properties (El-Baroty et al., 2017). The ability to adapt, grow effectively and potential to serve as additives in food, bio-fertilizer, sodic soil refining, and important source of biofuel are few amongst macroalgal distinguishing features.

Algae come in sizes from as small as $1 \mu \mathrm{m}$ to macro-sized seaweeds that may enlarge to over fifty meters (Pereira et al., 2021). According to Aslam et al. (2010) red algal extract (Lithothatmnion calcareum) has substantial mineral content and this leads to its utilization in animal and human food. Shalaby (2011) coined out that, seaweed consists of remarkable secondary metabolites such as phenolic compounds, 
unsaturated fatty acids, carotenoids, phycobiliprotein pigments, polysaccharides. Some of the natural algal products were proven to have different biological activities, including anticancer activity, antioxidant activity, antimicrobial activities against virus, bacteria, and fungi, bioremediation potentials and organic fertilizer. Majority of these compounds are produced in macroalgae at the last stage of their growth and/or as a result of environmental stress inducing some alterations in metabolic pathways. The potential for seaweed has been studied in the agricultural sector and the need to explore the more potentialities is of great advantage. According to Nabti et al. (2016) macroalgae are rich in diverse compounds like antimicrobial compounds and minerals, phytohormones, osmoprotectants, lipids, proteins, carbohydrates and amino acids. The advantages of agricultural applications of seaweed are numerous and diverse including frost and saline resistance, fertilization, improving health and growth of plants namely shoot and root elongation, improved water and nutrient uptake, stimulation of seed germination, biocontrol and resistance toward phytopathogenic organisms and remediation of pollutants in contaminated soil (Nabti et al., 2016). Macroalgae have such ability to reduce uptake of contaminants at the same supply nutrient for plants' development. Integrating soil with seaweed rise plant micro- and macronutrients and improve soil biological and physicochemical properties (Khan et al., 2009). The application of algae to remediate environmental contamination known as phycoremediation is a trending issue round the globe. Through photosynthesis, algae fix abundant $\mathrm{CO}_{2}$ and eradicate excess nutrients effectively at a minimal cost also harmful materials and pathogens are removed from waste water. Xenobiotics, heavy metals and other chemicals are known to be depolluted, altered, accumulated or volatilized by algal metabolism (Sunday et al., 2011). This review paper aimed at exploring the role macroalgae plays in improving plant growth and development, quality of plant product, preventing topsoil, relieve abiotic stress and remediation of environmental contaminants.

\section{USE AS FERTILIZER AND SOIL REVIVAL}

Food demand is among the foremost issues that attract global attention due to rapid population growth and plant growth slows down drastically due to a decrease in soil fertility and the ability to support the growth of different plants species. Deficiency in macro and micronutrients, soil pH amongst others are the major contributing factors. Inorganic fertilizer has been reported to pollute the environment, hence the need to devise other means to supplement nutrients required for plant growth and development. It has been reported that, along the coastal regions, seaweed has been applied to amend the soil either directly or in the composted form to achieve excellent crop production and where there is nutrient insufficiency to reclaimed alkaline soils (Zodape, 2001; Craigie, 2011). One distinguishing benefit of seaweed is their ability to condition the soil and be used to green manure (Rao et al., 2018). Previous researches have proved that Seaweed Fertilizer (SF) is better and eco-friendly than other chemical fertilizers (Anantharaj $\&$ Venkatesalu, 2002) as no pollution is reported upon the use of green manure. Seaweed potential to supplement soil with the macronutrients such as Magnesium, Calcium, Potassium, Phosphorus, Nitrogen, Sulfur, plant growth regulators; Cytokinins, Auxins and Gibberellins and trace elements like $\mathrm{Cu}, \mathrm{Zn}$, and Mn has been documented (Rengasamy, 2004). When applied to flowers, crops, vegetables and fruit, some improvements included increased nutrients uptake, higher yields, improved vigor, increased level of resistance to some pests and diseases, the extended shelf life of fruit, seed germination enhancement, and improved defense against abiotic stresses (Chatzissavvidis \& Therios, 2014). Seaweed manure is proven to be more important than chemical fertilizers due to its richness in organic matter, help in retaining moisture and adding minerals as well as making them accessible to plant roots in the upper soil level (Jothinayagi \& Anbazhagan, 2009). Raghunandan et al. (2019) reported that presence of fatty acid, carbohydrate and protein in seaweed facilitates nutrient and moisture retention in the soil which in turn improve soil texture and stimulate activities of soil microorganisms.

A significant quantity of alginate in brown algae which contains complex chains helps to anchor topsoil tightly together thus preventing soil losses. Seaweed-based manure establishes a good environmental condition for root growth by promoting microbial activities such as mineralization of nutrients and mobilization as well as favoring microbial diversity formation (Selvaraj et al., 2004; Battacharya et al., 2015). Soil reaction can be considered a crucial factor that triggers multiform of other proprieties of soil and positive effect to plant growth. The activity of microorganisms, availability and solubility of nutrients are some of the most crucial processes which indeed depend on $\mathrm{pH}$. The cell wall matrix of Rhodophytes consist of sulphated galactan which serves as a protective cover against extreme changes in $\mathrm{pH}$, temperature and salinity of soil (Lim et al., 2018). Sen et al. (2014) established that utilization of Ascophyllum spp. as a conditioner to soil averts losses of soil's top. Nostoc muscorum promotes stability in saline soil, where mostly soil aggregation is attributed to the release of exopolysaccharide by microorganisms or supplemented to the soil after death and cellular lysis (Singh, 2014). It has been reported that brown seaweed sargassum is valuable manure since they contain a significant amount of alginate which serves as a soil conditioner and alginic acid that accelerate the decomposition of organic matter by bacteria thereby increasing soil humus and nutrient (Zodape, 2001). Alginate and humic acid present in seaweed contribute to the formation of soil aggregate in the nonporous soil containing clay with minimum organic material. Soil aggregate provide more space for air, water, shelter for microorganisms and circulation of nutrient.

\section{PLANT STRESS ALLEVIATION}

Abiotic stresses including temperature (heat and cold), salinity and drought are universal problem distressing land overtop 800 million hectares, result in the immensely negative impact to plant productivity (Ferchichi et al., 2018). Various abiotic factors such as temperature salinity, and drought, are displayed as osmotic stress and this trigger secondary effects such as 
oxidative stress, resulting in accumulation of reactive oxygen species (ROS) like superoxide anion $\left(\mathrm{O}_{2}{ }^{--}\right)$and hydrogen peroxide $\left(\mathrm{H}_{2} \mathrm{O}_{2}\right)$ (Mittler, 2002; Khan et al., 2009).

Saline soils are the soils that contain a significant amount of sodium salt mainly $\mathrm{Na}_{2} \mathrm{SO}_{4}$ or $\mathrm{NaCl}$ whereas $\mathrm{NaHCO}_{3}$ and $\mathrm{Na}_{2} \mathrm{CO}_{3}$ found in alkaline soil both of which have an influential effect on the soil properties (Singh \& Dhar, 2010). The ability of salt stress to cause a drastic decline in vegetative growth, yield and quality of fruit has been established (Hegazi et al., 2014). Seaweeds provide excellent bioactive materials useful for salinity stress alleviation. Slight stress due to salinity could inflict blighting water-cell relations, physiological drought in plants, impairment of cell expansion, and consequential growth fare reduction (Hasegawa et al., 2000). In alkaline soil, both soluble and solid salts are found in higher concentrations which results in osmotic pressure leading to poor quality agricultural products. Prolong exposure time to elevated salinity result in ionic stress creating a disturbance in the intracellular ions homeostasis, which induce dysfunction of membrane and metabolic activity diminution and growth inhibition, and impose cell death (Hasegawa, 2013). High osmolarity inhibits plant growth-promoting rhizobacteria activity which in turn affects plant growth and productivity. Previous studies proved that the application of a number of kinds of Ascophyllum species improved salinity stress tolerance in many plants (Bonomelli et al., 2018; Jolinda et al., 2018). A. nodosum, enhances the accumulation of antioxidants, minerals, and essential amino acids in tomato fruits grown under salinity stress. It has reported been by Abdel-Latef et al. (2017) that Sargassum muticum and Jania rubens seaweeds have the ability to ameliorate sodium chloride salt stress in chickpea. According to Subramanian et al. (2011) alginate, diverse polysaccharides and some sulphated compounds were depicted to trigger directly the growth of root and indirectly guild with microbes and energize the plants' defensive mechanisms and persuade genes involve in pathogenesis-related defense in plants (Vera et al., 2011). The calcareous red seaweeds algae, $L$. corallioides and P. calcareum are applied to neutralize acid soils, as an agricultural lime substitute (McHugh, 2003).

Drought the global concern about the availability of water for agricultural use is has been increasing. Amongst abiotic stresses, drought is one of the foremost issues decreasing crop productivity in many parts of the world (Faroog et al., 2009). Plant physiology and crop productivity have been affected by drought stress (Table 1). Drought affects plants by inducing

Table 1: Algal species for alleviation of soil salinity stress for some crops

\begin{tabular}{lll}
\hline Seaweed Spp. & Crop & Reference \\
\hline A. brasilense & V. faba & (Hamaoui et al., 2001) \\
A. brasilense & C. arietinum & (Hamaoui et al., 2001) \\
H. diazotrophicus & H. vulgare & (Suarez et al., 2015) \\
A. chrococcum & Z. mays & (Rojas-Tapias et al., 2012) \\
A. brasilense & L. sativa & (Fasciglione et al., 2015) \\
P. dispersa & C. annuum & (Del Amor et al., 2012) \\
Brasilense/P. dispersa & C. annuum & (Nair et al., 2012) \\
SWE & A. thaliana & (Nair et al., 2012) \\
\end{tabular}

the production and accumulation of abscisic acid (ABA) which regulates closure of stomata causing impairment in the photosynthetic pathway (Chaves et al., 2009). Due to the complex metabolic pathways involved in drought tolerance, very little achievement was attained in generating drought-tolerant crop varieties by means of genetic engineering. Hence, devising biological processes to alleviate drought stress in plants is the better alternative. The use of seaweed extracts can alleviate production decline through the improvement of the antioxidant system and synthesis of compatible osmolytes. Shukla et al. (2017) documented the ability of Ascophyllum nodosum extract (ANE) to alleviate drought stress in soybean where they observed $50 \%$ higher relative content in the Ascophyllum nodosum extract treatment and reduced the degree of wilting of soybean grown under the influences of imposed drought conditions treated plants compare with control. Seaweed extract (SWE) of Fucus spiralis (macroalgae) was also found suitable in boosting Salvia officinalis growth and development under extreme water deficit (Mansori et al., 2019).

Treating drought stressed Arabidopsis plant with Ascophyllum nodosum extract reduces water lost by inducing concrete stomatal conductance control, maintaining the relative higher value of water use and mesophyll conductance during the last dehydration phase, prevent irreversible photosynthetic apparatus damages evoke pre-induced pathways for antioxidant defense system in combination with a more efficient energy dissipation mechanism were reported (Santaniello et al., 2017). Macronutrients content of leaf, growth and increase in resistance to drought was reported in grapes when treated with seaweed extract (Mancuso et al., 2006).

\section{SEAWEED FOR PHYCOREMEDIATION}

Toxic metals and organic pollutants are well-thought-out to be an obviously environmental challenge for animals and human health glob round. Due to urbanization, anthropogenic activities of different sources cause the increase in contamination of both terrestrial and aquatic by toxic metals and organic pollutants.

Phytoremediation involves the remediation of contaminants in a water body using algae (micro- and macroalgae). Fixation of $\mathrm{CO}_{2}$ through photosynthesis and removal of extra nutrients effectively is achieved by algae at a minimal cost. It gets rid of pathogens and other toxic material from the water. Through the metabolic process, algae transform, accumulate, detoxify and/ or convert into gasses (volatilization) xenobiotics such as heavy metals and other chemicals (Sunday et al., 2018).

It offers an advantage over conventional methods of remediation by its effectiveness, efficiency and eco-friendly nature (Sunday et al., 2018). Algae use the wastes as nutrients and enzymatically degrade the pollutants. Several algal features have qualified them model icons for the selective elimination and amassing of heavy metals which comprise great ability to tolerate exposure to heavy metals, competence to grow under both autotrophic and heterotrophic condition, the potentiality for genetic manipulation, phototaxy, phytochelatin expression, 
and enormous surface area: volume ratios (Kaur et al., 2019). The biosorption of HM ions by seaweed biomass may be achieved by different mechanisms such as complex formation, ion exchange, and electrostatic interaction (Mata et al., 2008) being ion exchange the most important (Michalak \& Chojnacka, 2010). Polysaccharides and proteins present in the algae cell walls provide the metal-binding sites (Gupta \& Rastogi, 2008).

Mehta and Gaur (2005) coined out that binding capacity of a seaweed cell surface to a specific ion rest on several factors including chemical state of these sites, the coordination number of the metal ion to be sorbed, the number of functional groups in the algae matrix, the availability of binding groups for metal ions, ability to form the complex and strong affinity of the metal to the functional group (Table 2).

\section{REMEDIATION OF HEAVY METAL}

According to Abbas et al. (2014) marine algae eliminate directly heavy metals from water that is contaminated by two systematic approaches; first by a metabolic-dependent absorption into their cells at low concentrations, and the next by adsorption process. Seaweed cell wall polysaccharides and their derivatives and proteins make available the binding sites of metal. Algae have various chemical moieties on their surface such as hydroxyl, carboxyl, phosphate, and amide, which act as metal-binding sites (Igiri et al., 2018) The sorption aptitude of a seaweed cell surface to a specific ion depends on more than a few factors such as the quantity of functional groups in the algal matrix, the number of coordination of the metallic ions to be sorbed, metal ions bioavailability, the ability of formation of complexes, to metal-to-functional group affinity and their chemical state (Ortiz-Calderon et al., 2017). Living algal cells, bioaccumulation of heavy metal is achieved by two routes: the first is achieved by binding of potentially toxic elements to the cell surface; and the second phase is the transport of metal ions into cells actively (Flouty et al., 2012). Algal cells in contaminated environment absorb heavy toxic metals which are translocated to the cell vacuole where they are accumulated. In this phase, binding proteins such as phytochelatins (PCs) and/or metallothioneins (MTs) bind to absorbed ions to prohibit toxic effects of accumulated metal ions in the host cell (Zeraatkar et al., 2016). Polymeric substances secreted extracellularly have the potential of binding cations and stabilize and make them less harmful and non-bioavailable metals in the environment (Figure 5).

Table 2: Colour and cell wall components of three classes of seaweed

\begin{tabular}{|c|c|c|}
\hline Division & Common name & Cell wall \\
\hline Chlorophyta & Green algae & $\begin{array}{l}\text { glucosides mannan, hydroxyproline, } \\
\text { xylans, and Cellulose } \\
\text { ( } \beta-1,4-\text { glucopyroside) }\end{array}$ \\
\hline Rhodophyta & Red algae & $\begin{array}{l}\text { Cellulose, xylans, several sulfated } \\
\text { polysaccharides (galactans) } \\
\text { calcification in some; alginate in } \\
\text { Corallinaceae }\end{array}$ \\
\hline Phaeophyta & Brown algae & $\begin{array}{l}\text { Cellulose, alginic, acid, and sulfated, } \\
\text { mucopolysaccharides (fucoidan) }\end{array}$ \\
\hline
\end{tabular}

Source: Ortiz-Calderon et al. (2017)
However, in the cells of non-living algal biomass, potentially toxic elements bind to the cell membrane surface. Hence, the process is known as an extracellular process (GodlewskaŻyłkiewicz, 2001). According to Zeraatkar et al. (2016) nonliving algal biomass is more encouraging as compared to living algae because of the large metal ions sorption capacity at a significant rate, and it does not require growing nutrients in a medium. Non-living algal biomass could be considered as a conglomeration of large and complex chain of molecules (such as lipids sugars, pectins, cellulose, proteins glycoproteins, etc.) (Arief et al., 2008) that act as adsorbents with binding affinity to heavy metal cations. Binding to heavy metals can be enhanced by either physical (drying, crushing, freezing, heating etc.)/ chemical treatment such as $\mathrm{CaCl}_{2}, \mathrm{NaOH}, \mathrm{HCl}$, formaldehyde, and glutaraldehyde (Bishnoi et al., 2007). Physical treatments influence the important role of the cell wall in biosorption of metal ions, as non-living cell membrane destruction provides more surface area to increase the biosorption capacity and release the cell contents for possible increase in binding cell components to metal ions whereas chemical treatment promote ion exchange when treated with $\mathrm{CaCl}_{2}$ as $\mathrm{Ca}$ binds to alginate (Bishnoi et al., 2007) cross linkage of functional group is promoted by Formaldehyde and glutaraldehyde (Ebrahimi et al., 2009), $\mathrm{NaOH}$ increase electrostatic interactions of metal ion cations while $\mathrm{HCl}$ dissolves polysaccharide, denature of the cell wall and improve biosorption (Rao et al., 2005). It has been reported that seaweed absorbed heavy metal from the soil and water bodies (Table 4).

\section{REMOVAL OF EXCESS NUTRIENT}

Anthropogenic such as fertilizer application, insecticide, industrial waste amongst others yields excessive inorganic nutrients such as phosphorus and nitrogen leading to eutrophication in water body (Camargo \& Alonso, 2006). Excessive non-metal nutrients from land to the body bodies is the principal water quality problem affecting the quality of coral reef health and loss of its communities which in turn cause a decrease in transparency of water and increase rate of fish mortality (Smith \& Schindler, 2009; Amin et al., 2018; Gasim

Table 3: Functional groups involve in biosorption of metals

\begin{tabular}{llll}
\hline Binding group & $\begin{array}{l}\text { Structural } \\
\text { formula }\end{array}$ & $\begin{array}{l}\text { Ligand } \\
\text { atom }\end{array}$ & $\begin{array}{l}\text { Occurrence in selected } \\
\text { biomolecules }\end{array}$ \\
\hline Hydroxyl & $-\mathrm{OH}$ & 0 & $\mathrm{PS}, \mathrm{UA}, \mathrm{SPS}, \mathrm{AA}$ \\
Phosphodiester & $\mathrm{P}-\mathrm{O}-\mathrm{OH}$ & 0 & $\mathrm{PL}$ \\
Carboxyl & $-\mathrm{C}=\mathrm{O}-\mathrm{OH}$ & $\mathrm{N}$ & $\mathrm{UA}, \mathrm{AA}$ \\
Amine & $\mathrm{NH} 2$ & $\mathrm{~N}$ & $\mathrm{Cto}, \mathrm{AA}$ \\
Sulfonate & $\mathrm{O}-\mathrm{S}=\mathrm{O}$ & 0 & $\mathrm{SPS}$ \\
Thioether & $-\mathrm{S}<$ & $\mathrm{S}$ & $\mathrm{AA}$ \\
Secondary amine & $\mathrm{NH}$ & $\mathrm{N}$ & $\mathrm{Cto}, \mathrm{PG}$, Peptide bond \\
Carbonyl (ketone) & $\mathrm{C}=\mathrm{O}$ & $\mathrm{O}$ & Peptide bond \\
Amide & $-\mathrm{C}=\mathrm{ONH} 2$ & $\mathrm{~N}$ & $\mathrm{AA}$ \\
Imine & $=\mathrm{NH}$ & $\mathrm{N}$ & $\mathrm{AA}$ \\
Imidazole & $\mathrm{C}-\mathrm{N}-\mathrm{H}$ & $\mathrm{N}$ & $\mathrm{AA}$ \\
Phosphonate & $-\mathrm{OH}-\mathrm{P}-\mathrm{O}-\mathrm{OH}$ & $\mathrm{O}$ & $\mathrm{PL}$ \\
Sulfhydryl (thiol) & $-\mathrm{SH}$ & $\mathrm{S}$ & $\mathrm{AA}$ \\
\hline
\end{tabular}

$\mathrm{PL}=$ Phospholipids; $\mathrm{LPS}=\mathrm{LipoPS} ; \mathrm{PS}=$ Polysaccharides; $\mathrm{UA}=$ Uronic acids; PG = Peptidoglycan; SPS = Sulfated PS; Cto = Chitosan; $\mathrm{AA}=$ Amino acids; $\mathrm{TA}=$ Teichoic acid. Adapted from Zeraatkar et al. (2016) 
Table 4: Sea weed as phytoremediators of heavy metals

\begin{tabular}{|c|c|c|}
\hline Seaweed & Toxic metal & Reference \\
\hline \multirow[t]{2}{*}{ Ascophyllum nodosum } & $\begin{array}{l}\text { Cobalt (Co) } \\
\text { Gold (Au) }\end{array}$ & $\begin{array}{l}\text { (Kuyucak et al., 1998) } \\
\text { (Kuyucak et al., 1998) }\end{array}$ \\
\hline & $\begin{array}{l}\text { Nickel }(\mathrm{Ni}) \\
\text { Lead }(\mathrm{Pb})\end{array}$ & (Holan, and Volesky, 1994) \\
\hline Caulerpa racemosa & Boron (B) & (Bursali et al., 2009) \\
\hline Fucus vesiculosus & $\begin{array}{l}\text { Nickel }(\mathrm{Ni}) \\
\text { Zinc }(\mathrm{Zn})\end{array}$ & $\begin{array}{l}\text { (Fourest and Volesky, 1997) } \\
\text { (Volland et al., 2013) }\end{array}$ \\
\hline $\begin{array}{l}\text { Micrasterias } \\
\text { denticulata }\end{array}$ & Cadmium (Cd) & (Volland et al., 2013) \\
\hline Laminaria japonica & Zinc $(Z n)$ & (Fourest \& Volesky, 1997) \\
\hline Phormedium bohner & Chromium $(\mathrm{Cr})$ & (Dwivedi et al., 2010) \\
\hline Sargassum fluitans & Copper (Cu) & (Davis et al., 2000) \\
\hline $\begin{array}{l}\text { Platymonas } \\
\text { subcordiformis }\end{array}$ & Strontium (Sr) & (Mei et al., 2006) \\
\hline \multirow[t]{2}{*}{ Sargassum filipendula } & $\begin{array}{l}\text { Copper }(\mathrm{Cu}) \\
\text { Zinc }(\mathrm{Zn})\end{array}$ & $\begin{array}{l}\text { (Davis et al., 2000) } \\
\text { (Fourest \& Volesky, 1997) }\end{array}$ \\
\hline & $\begin{array}{l}\text { Iron }(\mathrm{Fe}) \\
\text { Cobalt }(\mathrm{Co}) \\
\text { Mercury }(\mathrm{Hg})\end{array}$ & $\begin{array}{l}\text { (Figueira et al., 1997) } \\
\text { (Kaewsarn \& Yu, 2001) }\end{array}$ \\
\hline Spirogyra hyalina & $\begin{array}{l}\text { Cadmium }(\mathrm{Cd}) \text {, } \\
\text { Lead }(\mathrm{Pb}) \text {, and } \\
\text { Arsenic (As) }\end{array}$ & \\
\hline Microchaete tenera & Lead Pb & (Gupta et al., 2013) \\
\hline Padina sp. & Cadmium (Cd) & (Kaewsarn \& Yu, 2001) \\
\hline $\begin{array}{l}\text { Chlamydomonas } \\
\text { reinhardtii }\end{array}$ & Mercury (Hg) & (Bayramo et al., 2008) \\
\hline Durvillaea potatorum & Cadmium (Cd) & (Deng et al., 2006) \\
\hline Ulva lactuca & Cadmium (Cd) & (Lupea et al., 2012) \\
\hline Sargassum sp. & Cupper (Cu) & (Karthikeyan et al., 2007) \\
\hline Ulva fasciata & Cupper (Cu) & (Karthikeyan et al., 2007) \\
\hline $\begin{array}{l}\text { Scenedesmus } \\
\text { quadricauda }\end{array}$ & Lead $(\mathrm{Pb})$ & (Mirghaffari et al., 2017) \\
\hline Spirogyra sp. & Chromium (Cr) & (Gupta et al., 2001) \\
\hline
\end{tabular}

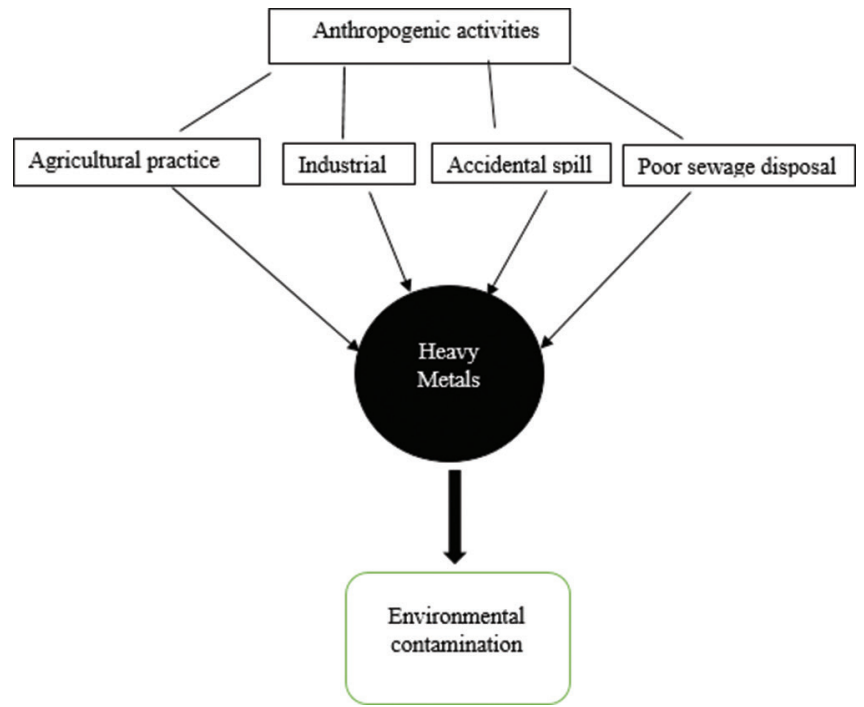

Figure 1: Schematic representation of heavy metals source by anthropogenic activities

et al., 2017; Ishak et al., 2018). Arumugam et al. (2018); He et al. (2008) documented the competency of seaweed in absorbing high nitrogen concentration and store in its tissue. Rathod et al. (2014); Chen et al. (2008) proved the mechanism involved physisorption by active site at the surface of biosorbent and hold by a chemical bond (chemisorption) while intracellular transfer is achieved by active transport followed by biotransformation and intracellular accumulation.

\section{CONCLUSION}

Seaweeds are both agricultural and environmental tools for mitigating pollution, soil reclamation and improvement of agricultural productivity. They absorb, transform and bioaccumulate heavy metals and other non-heavy ones from the environment. Though researches have been previously reported, other species of algae need to be explored most especially dry biomass. Nevertheless, the need to explore tremendous applications of seaweed in these fields is still required.

\section{ACKNOWLEDGMENT}

This study was funded by FRGS (Project code: FRGS/1/2019/ WAB01/UNISZA/02/2), Ministry of High Education and supported by Universiti Sultan Zainal Abidin, Besut campus, 22200 Besut, Terengganu, Malaysia. The Authors would like to thank the Center for Research Excellence and Incubation Management (CREIM), Universiti Sultan Zainal Abidin (UniSZA), Terengganu, Malaysia for publication support.

\section{REFERENCE}

Abbas, H. S., Ismail, M. I., Mostafa, M. T. \& Sulaymon, H. A. (2014). Biosorption of heavy metals: A review. Journal of Chemical Science and Technology, 3, 74-102,

Abdel-Latef, A. A. H., Srivastava, A. K., Saber, H., Alwaleed, E. A., \& Tran, L.-S. P. (2017). Sargassum muticum and Jania rubens regulate amino acid metabolism to improve growth and alleviate salinity in chickpea. Scientific Reports, 7(1), 10537. https://doi:10.1038/ s41598-017-07692-w

Amin, S. N. S. M., Azid, A., Khalit, S. I., Samsudin, M. S., \& Yusof, K. M. K. K. (2018). The association of heavy metals concentration in air and health risk assessment in Paka, Malaysia. Malaysian Journal of Fundamental and Applied Sciences, 10(2-1), 346-349. https://doi.org/10.11113/mjfas.v15n2-1.1561

Anantharaj, M., \& Venkatesalu, V. (2002). Studies on the effect of seaweed extracts on Dolichos biflorus. Seaweed Research and Utilisation, 24(1), 129-137.

Arief V. O., Trilestari K., Sunarso J., Indraswati N.,\& Ismadji S. (2008). Recent progress on biosorption of heavy metals from liquids using low cost biosorbents: Characterization, biosorption parameters and mechanism studies. CLEAN-Soil Air Water, 36, 937-962. https://doi. org/10.1002/clen.200800167

Arumugam, N., Chelliapan, S., Kamyab, H., Thirugnana, S., Othman, N., \& Nasri, N. (2018). Treatment of Wastewater Using Seaweed: A Review. International Journal of Environmental Research and Public Health, 15(12), 2851. https://doi.org/10.3390/ijerph15122851

Aslam, M. N., Kreider, J. M., Paruchuri, T., Bhagavathula, N., DaSilva, M., Zernicke, R. F., Goldstein, S. A., \& Varani, J. (2010). A mineral-rich extract from the red marine algae Lithothamnion calcareum preserves bone structure and function in female mice on a Western-style diet. Calcified Tissue International, 86(4), 313-324. https://doi.org/10.1007/s00223-010-9340-9

Battacharya, D., Babbohari, M. Z., Rathor, P. \& Prithiviraj, B. (2015). Seaweed extracts as biostimulants in horticulture. Scientia Horticulturae, 196 , 39-48. https://doi.org/10.1016/j.scienta.2015.09.012

Bayramo` G., Tuzun, I., Celik, G., Yilmaz, M., \& Arica, M. Y. (2006). Biosorption of mercury (II), cadmium (II) and lead (II) ions from aqueous system by microalgae Chlamydomonas reinhardtii immobilized in alginate 
beads. International Journal of Mineral Processing, 81(1), 35-43. https://doi.org/10.1016/j.minpro.2006.06.002

Bishnoi, N. R., Kumar, R., Kumar, S., \& Rani, S. (2007). Biosorption of Cr(III) from aqueous solution using algal biomass spirogyra spp. Journal of Hazardous Materials, 145(1-2), 142-147. https://doi:10.1016/j. jhazmat.2006.10.093

Bonomelli, C., Celis, V., Lombardi, G., \& Mártiz, J. (2018). Salt stress effects on avocado (Persea americana Mill.) plants with and without seaweed extract (Ascophyllum nodosum) Application. Agronomy, 8(5), 64. https://doi.org/10.3390/agronomy8050064

Bursali, E. A., Cavas, L., Seki, Y., Bozkurt, S. S., \& Yurdakoc, M. (2009). Sorption of boron by invasive marine seaweed: Caulerpa racemosa var. cylindracea. Chemical Engineering Journal, 150, 385. http://doi. org/10.1016/j.cej.2009.01.016

Camargo, J. A., \& Alonso, Á. (2006). Ecological and toxicological effects of inorganic nitrogen pollution in aquatic ecosystems: A global assessment. Environment International, 32(6), 831-849. https://doi. org/10.1016/j.envint.2006.05.002

Chatzissavvidis, C., \& Therios, I. (2014). Role of Algae in Agriculture. In: Seaweeds. Nova Science Publishers, Inc. 1-37

Chaves, M.M., Flexas, J., \& Pinheiro, C. (2009). Photosynthesis under drought and salt stress: regulation mechanisms from whole plant to cell. Annals of Botany, 103(4), 551-560. https://doi.org/10.1093/ aob/mcn 125

Chen, C., \& Wang, J. (2008). Removal of $\mathrm{Pb}^{2+}, \mathrm{Ag}^{+}, \mathrm{Cs}^{+}$and $\mathrm{Sr}^{2+}$ from aqueous solution by brewery's waste biomass. Journal of Hazardous Materials, 151(1), 65-70. https://doi.org/10.1016/j. jhazmat.2007.05.046

Craigie, J. S. (2011). Seaweed extract stimuli in plant science and agriculture. Journal of Applied Phycology, 23, 371-393. https://doi. org/10.1007/s10811-010-9560-4

Davis, T. A., Volesky, B., \& Vieira, R. H. S. F. (2000). Sargassum Seaweed as Biosorbent for Heavy Metals. Water Research, 34(17), 4270-4278. https://doi.org/10.1016/S0043-1354(00)00177-9

Dawson, E. Y. (1966). Marine Botany: An Introduction. Holt, Rinehart and Winston, Inc. New York. 371

Del Amor, F. M., \& Cuadra-Crespo, P. (2012). Plant growth-promoting bacteria as a tool to improve salinity tolerance in sweet pepper. Functional Plant Biology, 39(1), 82-90. https://doi.org/10.1071/ FP11173

Deng, L., Su, Y., Su, H., Wang, X., \& Zhu, X. (2006). Biosorption of copper (II) and lead (II) from aqueous solutions by nonliving green algae Cladophora fascicularis: Equilibrium, kinetics and environmental effects. Adsorption, 12(4), 267-277. https://doi.org/10.1007/s10450006-0503-y

Dos Reis, S. P., Lima, A. M., \& de Souza, C. R. (2012). Recent molecular advances on downstream plant responses to abiotic stress. International Journal of Molecular Science, 13(7), 8628-8647. https:// doi.org/10.3390\%2Fijms13078628

Dwivedi, S., Srivastava, S., Mishra, S., Kumar, A., Tripathi, R. D., Rai, U. N., \& Trivedi, P. K. (2010). Characterization of native microalgal strains for their chromium bioaccumulation potential: Phytoplankton response in polluted habitats. Journal of Hazardous Materials, 173(1-3), 95-101. https://doi.org/10.1016/j.jhazmat.2009.08.053

Ebrahimi, M., Panahi, R., \& Dabbagh, R. (2009). Evaluation of native and chemically modified Sargassum glaucescens for continuous biosorption of Co (II). Applied Biochemistry Biotechnology, 158(3), 736-746. https://doi.org/10.1007/s12010-008-8389-7

El-Baroty, G.S., Moussa, M. Y., Shallan, M.A., Ali, M. A., Sabh, A. Z., \& Shalaby, E. A. (2007). Contribution to the aroma, biological activities, minerals, protein, pigments and lipid contents of the red alga: Asparagopsis taxiformis (Delile) Trevisan. Journal of Applied Science Research, 3, 1825-1834.

Fakhry, E. (2013). Padina pavonica for the Removal of Dye from Polluted Water. American Journal of Plant Sciences, 4(10), 1983-1989. https:// doi.org/10.4236/ajps.2013.410246

Farooq, M., Wahid, A., Kobayashi, N., Fujita, D. \& Basra, S. M. A. (2009). Plant drought stress: effects, mechanisms and management. Agronomy for Sustainable Development, 29(1), 185-212. https://doi. org/10.1051/agro:2008021

Fasciglione, G., Casanovas, E. M., Quillehauquy, V., Yommi, A. K., Goñi, M. G., \& Roura, S. I. (2015). Azospirillum inoculation effects on growth, product quality and storage life of lettuce plants grown under salt stress. Scientia Horticulturae, 195,154-62. https://doi.org/10.1016/j. scienta.2015.09.015

Ferchichi, S., Hessini, K., Dell'Aversana, E., D’Amelia, L., Woodrow, P., \& Ciarmiello, L. F. (2018). Hordeum vulgare and Hordeum maritimum respond to extended salinity stress displaying different temporal accumulation pattern of metabolites. Functional Plant Biology, 45, 1096-1109. https://doi.org/10.1071/FP18046

Figueira, M. M., Volesky, B., \& Ciminelli, V. S. T. (1997). Assessment of interference in biosorption of a heavy metal. Biotechnol Bioengineering, 54, 344-350. https://doi.org/10.1002/(SICI)1097-0290

Flouty, R., \& Estephane, G. (2012). Bioaccumulation and biosorption of copper and lead by a unicellular algae Chlamydomonas reinhardtii in single and binary metal systems: a comparative study. Journal of Environment Management, 111(8), 106-14. https://doi.org/10.1016/j. jenvman.2012.06.042

Fourest, E., \& Volesky, B. (1997). Alginate properties and heavy metal biosorption by marine algae. Applied Biochemistry \& Biotechnology, 67(1), 33-44. https://doi.org/10.1007/BF02788799

Gasim, M. B., Toriman, M. E., Barggig, A., Mutfah, S., Hairoma, N., \& Endut, A. (2017). The evaluation of heavy metals concentrations in Cempaka Lake, Bangi, Selangor, Malaysia. International Journal on Advanced Science, Engineering and Information Technology, 7(2), 453-459. http://doi.org/10.18517/ijaseit.7.2.1004

Godlewska-Żyłkiewicz, B. (2001). Analytical applications of living organisms for preconcentration of trace metals and their speciation. Critical Review Annual Chemistry, 31, 175-189. https://doi org/10.1080/20014091076730

Goecke, F., Labes, A., Wiese, J., \& Imhoff, J. (2010). Chemical interactions between marine macroalgae and bacteria. Marine Ecology Progress Series, 409, 267-299. https://doi.org/10.3354/meps08607

Gupta, D. K., Huang, H. G., \& Corpas, F. J. (2013). Lead tolerance in plants: strategies for phytoremediation. Environmenta/ Science and Pollution Research, 20,150-2161. https://doi.org/10.1007/s11356-013-1485-4

Gupta, V. K., \& Rastogi A. (2008). Biosorption of lead from aqueous solutions by green algae Spirogyra species: kinetics and equilibrium studies. Journal of Hazardous Materials, 152(1), 407-414. https://doi. org/10.1016/j.jhazmat.2007.07.028

Gupta, V. K., Shrivastava, A. K., \& Jain, N. (2001). Biosorption of Chromium (VI) From Aqueous solutions by green algae spirogyra species. Water Research, 35(17), 4079-4085. https://doi.org/10.1016/S0043 1354(01)00138-5

Hamaoui, B., Abbadi, J., Burdman, S., Rashid, A., Sarig, S., \& Okon, Y. (2001). Effects of inoculation with Azospirillum brasilense on chickpeas (Cicer arietinum) and faba beans (Vicia faba) under different growth conditions. Agronomy, 21(6-7), 553-60. https://doi.org/10.1051/ AGRO\%3A2001144

Hasegawa, P. M. (2013). Sodium ( $\left.\mathrm{Na}^{+}\right)$homeostasis and salt tolerance of plants. Environmental and Experimental Botany, 92, 19-31. https:// doi.org/10.1016/j.envexpbot.2013.03.001

Hasegawa, P. M., Bressan, R. A., Zhu, J. K., \& Bohnert, H. J. (2000). Plant cellular and molecular responses to high salinity. Annual Review of Plant Physiology and Plant Molecular Biology, 51, 463-499. https:// doi.org/10.1146/annurev.arplant.51.1.463

He, P., Xu, S., Zhang, H., Wen, S., Dai, Y., Lin, S.,\& Yarish, C. (2008) Bioremediation efficiency in the removal of dissolved inorganic nutrients by the red seaweed, Porphyra yezoensis, cultivated in the open sea. Water Research, 42(4-5), 1281-1289. https://doi. org/10.1016/j.watres.2007.09.023

Hegazi, A. M., El-Shraiy, A. M., \& Ghoname, A. A. (2014). Alleviation of Salt Stress Adverse Effect and Enhancing Phenolic Antioxidant Content of Eggplant by Seaweed Extract. Gesunde Pflanzen, 67(1), 21-31. https://doi.org/10.1007/s10343-014-0333-x

Holan, Z. R., \& Volesky, B. (1994). Biosorption of lead and nickel by biomass of marine algae. Biotechnology and Bioengineering, 43(11), 1001-1009. https://doi.org/10.1002/bit.260431102

Igiri, B. E., Okoduwa, S. I. R., Idoko, G. O., Akabuogu, E. P., Adeyi, A. O. \& Ejiogu, I. K. (2018). Toxicity and bioremediation of heavy metals contaminated ecosystem from tannery wastewater: A review. Journal of Toxicology, 2018, 1-16. https://doi.org/10.1155/2018/2568038

Ishak, M. F. B., Abdullah, T. A., Sajili, M. H., Mahmud, K., \& Mohamed, S (2018). The Effect of Bacillus sp.(B43) on the growth of Pak choy and Red tilapia in aquaponics system. Journal of Agrobiotechnology, 9(1S), 154-165

Jolinda M., Leitão E. T., Gomes C. D., Rodrigues M. H., Valéria F. D. O. \& dos Santos G. L., (2018). The initial growth of passion fruit plant irrigated 
with saline water and the application of biostimulants. Journal of Agriculture Science, 10 357-363. https://doi.org/10.5539/jas. v10n9p357

Jothinayagi, N., \& Anbazhagan, C. (2009). Effect of Seaweed Liquid Fertilizer of Sargassum wightii on the growth and biochemical characteristics of Abelmoschus esculentus (L.) Medikus. Recent Research Science Technology, 1(4), 155-158.

Kaewsarn, P., \& Yu, Q. (2001). Cadmium (II) removal from aqueous solutions by pre-treated biomass of marine alga adina $\mathrm{sp}$. Environmental Pollution, 112, 209-213. https://doi.org/10.1016/ s0269-7491(00)00114-7

Karthikeyan, S., Balasubramanian, R., \& lyer, C. S. P. (2007). Evaluation of the marine algae U/va fasciata and Sargassum sp. for the biosorption of $\mathrm{Cu}$ (II) from aqueous solutions. Bioresources Technology, 98, 452-455. https://doi.org/10.1016/j.biortech.2006.01.010

Kaur, H., Rajor, A., \& Kaleka, A. S. (2019). Role of phycoremediation to remove heavy metals from sewage water: Review article. Journal of Environmental Science and Technology, 12, 1-9. https://doi. org/10.3923/jest.2019.1.9

Khan, W., Rayirath, U. P., Subramanian, S., Jithesh, M. N., Rayorath, P., Hodges, D. M., \& Prithiviraj, B. (2009). Seaweed extracts as biostimulants of plant growth and development. Journal of Plant Growth Regulation, 28(4), 386-399. https://doi.org/10.1007/s00344009-9103-x

Kuyucak, N., \& Volesky, B. (1988). Biosorbents for recovery of metals from industrial solutions. Biotechnology Letters, 10(2), 137-142. https:// doi.org/10.1007/BF01024641

Kuyucak, N., \& Volesky, B. (1989). Desorption of cobalt-laden algal biosorbent. Biotechnology and Bioengineering, 33(7), 815-822. https://doi.org/10.1002/bit.260330704

Lim, Y., Lee, W., Leow, T. A., Namasivayam, P., Abdullah, J., \& Ho, C. (2018). Sulfated galactans from red seaweeds and their potential applications. Pertanika Journal of Scholarly Research Reviews, 4(2), 1-17.

Lupea, M., Bulgariu, L., \& Macoveanu, M. (2012). Biosorption of Cd (II) from aqueous solution on marine green algae biomass. Environmental Engineering and Management Journal, 11, 607-615. https://doi. org/10.30638/eemj.2012.076

Mancuso, S., Azzarello, E. Mugnai S., \& Briand, X. (2006). Marine bioactive substances (IPA extract) improve ion fluxes and water stress tolerance in potted Vitis vinifera plants. Advances in Horticultural Science, 20, 156-161.

Mansori, M., Farouk, I. A., Hsissou, D., \& El Kaoua, M. (2019). Seaweed extract treatment enhances vegetative growth and antioxidant parameters in water stressed Salvia officinalis L. Journal of Materials and Environmental Science, 10(8), 756-766.

Mata, Y. N., Blázquez, M. L., Ballester, A., González, F., \& Muñoz J. A. (2008). Characterization of the biosorption of cadmium, lead and copper with the brown alga Fucus vesiculosus. Journal of Hazardous Materials, 158(2-3), 316-323. https://doi.org/10.1016/j.jhazmat.2008.01.084

McHugh, D. J. (2003). A guide to the seaweed industry. FAO Fisheries Technical Paper. No. 441. Rome, FAO. 105

Mehta, S. K., \& Gaur, J. P. (2005). Use of algae for removing heavy metal ions from wastewater: progress and prospects. Critical Reviews in Biotechnology, 25(3), 113-152. https://doi. org/10.1080/07388550500248571

Mei, L., Xitao, X., Renhao, X., \& Zhili, L. (2006). Effects of strontiuminduced stress on marine microalgae Platymonas subcordiformis (Chlorophyta: Volvocales). Chinese Journal of Oceanology and Limnology, 24(2), 154-160. https://doi.org/10.1007/BF02842815

Michalak, I., \& Chojnacka, K. (2010). Interactions of metal cations with anionic groups on the cell wall of the macroalga Vaucheria $\mathrm{sp}$. Engineering in Life Sciences, 10(3), 209-217. https://doi.org/10.1002/ elsc.200900039

Mirghaffari, N., Moeini, E., \& Farhadian, O. (2015). Biosorption of Cd and $\mathrm{Pb}$ ions from aqueous solutions by biomass of the green microalga, Scenedesmus quadricauda. Journal of Applied Phycology, 27(1), 311-320. https://doi.org/10.1007/s10811-014-0345-z

Mittler, R. (2002). Oxidative stress, antioxidants and stress tolerance. Trends Plant in Science, 7, 405-410. https://doi.org/10.1016/s13601385(02)02312-9

Nabti, E., Jha, B., \& Hartmann, A. (2016). Impact of seaweeds on agricultural crop production as biofertilizer. International Journal of Environmental Science and Technology, 14(5), 1119-1134. https://doi.org/10.1007/ s13762-016-1202-1

Nair, P., Kandasamy, S., Zhang, J., Ji, X., Kirby, C., \& Benkel, B. (2012). Transcriptional and metabolomic analysis of Ascophyllum nodosum mediated freezing tolerance in Arabidopsis thaliana. BMC Genomics, 13(1), 643. https://doi.org/10.1186/1471-2164-13-643

Okolie, C. L., Mason, B., \& Critchley, A. T. (2018). Seaweeds as a source of proteins for use in pharmaceuticals and high-value applications. in Novel Proteins for Food, Pharmaceuticals, and Agriculture: Sources, Applications, and Advances, ed. Hayes M., editor. (Hoboken, NJ: Wiley) 217

Ortiz-Calderon, C., Silva, H. C., \& Vásquez, D. B. (2017). Metal Removal by Seaweed Biomass. Biomass Volume Estimation and Valorization for Energy, https://doi.org/10.5772/65682

Pereira, L. (2021). Macroalgae. Encyclopedia, 1, 177-188. https://doi org/10.3390/encyclopedia1010017

Raghunandan, B. L., Vyas, R. V., Patel, H. K., \& Jhala, Y. K. (2019). Perspectives of Seaweed as Organic Fertilizer in Agriculture. Soil Fertility Management for Sustainable Development, 267-289. https:// doi.org/10.1007/978-981-13-5904-0 13

Rao S., P., Kalyani, S., Reddy S., K. V. N., \& Krishnaiah, A. (2005). Comparison of biosorption of nickel (II) and copper (II) ions from aqueous solution by sphaeroplea algae and acid treated sphaeroplea algae. Separation Science and Technology, 40(15), 3149-3165. https://doi. org/10.1080/01496390500385350

Rao, S. P. V., Periyasamy, C., Kumar, S. K., Rao, S. A., \& Anantharaman, P. (2018). Seaweeds: distribution, production and uses. Bioprospecting of Algae, 59-78

Rathod, M., Mody, K., \& Basha, S. (2014). Efficient removal of phosphate from aqueous solutions by red seaweed, Kappaphycus alverezii. Journal of Cleaner Production, 84, 484-493. http://doi.org/10.1016/i. jclepro.2014.03.064

Rengasamy, R. (2004). Cultivation of shrimp with seaweeds. National workshop on seaweed farming and processing for food. Kilakarai, India.

Rojas-Tapias, D., Moreno-Galván, A., Pardo-Díaz, S., Obando, M., Rivera, D., \& Bonilla, R. (2012). Effect of inoculation with plant growthpromoting bacteria (PGPB) on amelioration of saline stress in maize (Zea mays). Applied Soil Ecology, 61, 264-72. http://doi.org/10.1016/j. apsoil.2012.01.006

Santaniello, A., Scartazza, A., Gresta, F., Loreti, E., Biasone, A., Di Tommaso, D., Piaggesi, A., \& Perata, P. (2017). Ascophyllum nodosum seaweed extract alleviates drought stress in arabidopsis by affecting photosynthetic performance and related gene expression. Frontiers in Plant Science, 8, 1362. https://doi.org/10.3389/fpls.2017.01362

Selvaraj, R., Selvi, M., \& Shakila, P. (2004). Effect of seaweed liquid fertilizer on Abelmoschus esculentus (L). Moench and Lycopersicon Iycopersicum Mill. Seaweed Research Utility, 26, 121-123.

Sen, A., Srivastava, V. K., Singh, R. K., Singh, A. P., Raha, P., Ghosh, A. K., \& Upadhyay, P. K. (2014). Soil and plant responses to the application of Ascophyllum nodosum extract to no-till wheat (Triticum aestivum L.). Communications in Soil Science and Plant Analysis, 46(1), 123-136. https://doi.org/10.1080/00103624.2014.956938

Shalaby, E. (2011). Algae as promising organisms for environment and health. Plant Signaling \& Behavior, 6(9), 1338-1350. https://doi. org/10.4161\%2Fpsb.6.9.16779

Shukla, P. S., Shotton, K., Norman, E., Neily, W., Critchley, A. T., \& Prithiviraj, B. (2017). Seaweed extract improve drought tolerance of soybean by regulating stress-response genes. AoB PLANTS, 10(1). https://doi.org/10.1093/aobpla/plx051

Singh, N. K., \& Dhar, D. W. (2010). Cyanobacteria/ Reclamation of SaltAffected Soil. Sustainable Agriculture Reviews, 20, 243-275. https:// doi.org/10.1007/978-90-481-8741-6_9

Singh, S. (2014). A review on possible elicitor molecules of cyanobacteria: their role in improving plant growth and providing tolerance against biotic or abiotic stress. Journal of Applied Microbiology, 117(5), 1221-1244. https://doi.org/10.1111/jam.12612

Smith, V. H., \& Schindler, D. W. (2009). Eutrophication science: where do we go from here? Trends in Ecology \& Evolution, 24(4), 201-207. https://doi.org/10.1016/j.tree.2008.11.009

Suarez, C., Cardinale, M., Ratering, S., Steffens, D., Jung, S., \& Montoya, A. M. Z. (2015). Plant growth-promoting effects of Hartmannibacter diazotrophicus on summer barley (Hordeum vulgare L.) under salt stress. Applied Soil Ecology, 95, 23-30. https://doi. org/10.1016/j.apsoil.2015.04.017 
Subramanian, S., Sangha, J. S., Gray, B. A., Singh, R. P., Hiltz, D., Critchley, A. T., \& Prithiviraj, B. (2011). Extracts of the marine brown macroalga, Ascophyllum nodosum, induce Jasmonic acid dependent systemic resistance in Arabidopsis thaliana against Pseudomonas syringae pv. tomato DC3000 and Sclerotinia sclerotiorum. European Journal of Plant Pathology, 131, 237-248. https://doi.org/10.1007/ s10658-011-9802-6

Sunday E. R., Uyi O. J., \& Caleb, O. O., (2018). Phycoremediation: An Eco-Solution to Environmental Protection and Sustainable Remediation. Journal of Chemical, Environmental and Biological Engineering, 2(1), 5-10. https://doi.org/10.11648/j.jcebe.20180201.12

Vera, J., Castro, J., Gonzalez, A., \& Moenne, A. (2011). Seaweed Polysaccharides and Derived Oligosaccharides Stimulate Defense
Responses and Protection Against Pathogens in Plants. Marine Drugs, 9(12), 2514-2525. https://doi.org/10.3390/md9122514

Volland, S., Schaumlöffel, D., Dobritzsch, D., Krauss, G. J., \& LützMeindl, U. (2013). Identification of phytochelatins in the cadmiumstressed conjugating green alga Micrasterias denticulata. Chemosphere, 91(4), 448-454. https://doi.org/10.1016/j. chemosphere.2012.11.064

Zeraatkar, A. K., Ahmadzadeh, H., Talebi, A. F., Moheimani, N. R., \& McHenry, M. P. (2016). Potential use of algae for heavy metal bioremediation, a critical review. Journal of Environmental Management, 181, 817-831. https://doi.org/10.1016/j.jenvman.2016.06.059

Zodape, S. T. (2001). Seaweeds as a biofertilizer. Journal of Scientific and Industrial Research, 60, 378-382. 